University for Business and Technology in Kosovo

UBT Knowledge Center

Nov 8th, 11:45 AM - 12:00 PM

\title{
Educational impact on business and management with special view in Gjakova municipality
}

\author{
Zymer Tafaj \\ zymertafaj@hotmai.com \\ Driton Imami \\ dritonimami@hotmail.com
}

Follow this and additional works at: https://knowledgecenter.ubt-uni.net/conference

Part of the Business Commons

\section{Recommended Citation}

Tafaj, Zymer and Imami, Driton, "Educational impact on business and management with special view in Gjakova municipality" (2014). UBT International Conference. 45.

https://knowledgecenter.ubt-uni.net/conference/2014/all-events/45

This Event is brought to you for free and open access by the Publication and Journals at UBT Knowledge Center. It has been accepted for inclusion in UBT International Conference by an authorized administrator of UBT Knowledge Center. For more information, please contact knowledge.center@ubt-uni.net. 


\title{
Educational impact on business and management with special view in Gjakova municipality
}

\author{
Zymer Tafaj ${ }^{1}$, Driton Imami ${ }^{2}$

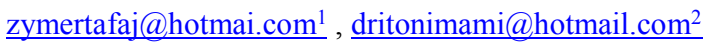

\begin{abstract}
This work elaborates the topic of effects of education in business and management with special view in Gjakova municipality, businesses these that are experiencing periods of after war transition reflecting attitudes of owners and managers how they perceive effects of education in business evolution and sustainability of businesses that they are governing. This work elaborates the topic effects of education in business and management with special view in Gjakova municipality, also it is shown what is the effect of education in creating an effective management structure, also actions that are taken from managers for educating their staff in order to have better prepared staff to face the intense competition and ensure survival in a unstable economy as in Republic Of Kosova. The work is done in two phases. First phase refers to collecting all data which are related to this topic. Second phase concerns the data collected in the field. Data collected on filed are qualitative, where are been interwiewed 30 owners and 50 managers that manage small and medium businesses in Gjakova are interviewed. Among main findings of the paper are that owners and managers are aware that education is a key and necessary element for the success and sustainability of their business, among other findings is that economic status that prevails in municipality brings a lot of difficulties in creating an adequate climate for their businesses.
\end{abstract}

Keywords: business, education, management, economy.

\section{Introduction}

This topic elaborates the effects of education into businesses and management with special wiew in Gjakova municipality, while the need for well educated work force is growing up day by day.

Education has allways been an important issue for an effective business and management, also the value of educaton is continuously growing up as a result of rapid changes and competitive pressure. So the success of a business and its effective management in most of the time depends on: education, knowledge, skills, experience and commitment of personel that uses that knowledge in achieving the objectives of organization.

In this work types of formal and informal education are treated and also the effects that include: organizational, individual, group, and finally the impact that education have in business and management. Special regard is given to effects and the need for education in Gjakova municipality. Education and knowledge are evaluated as a business capital, this assets are workers and leaders and the need for knowledge is continuously growing, nowdays it is considered that education and development are the main priorities of each business and management. Becouse through education human resources can achieve knowledge and capabilities to be more effective when they face challenges of changes and tough concurrence. Management understanding more and more that education and continuous perfection is the only and more effective way for realizing the priority of competition, to get in the race of market to gain the costumers trust as a base for business to exist.

As intent of this work is the explanation of the effect of education in business and management based on the perception of actors of municipality of Gjakova. Through this research it is attempted the reflection of attitudes of owners and managers of businesses in Gjakova municipality for the effects of personel education and recomandations for possible solutions.

The data has been taked an interviev.the data that hav been collected are quality data 30 owners and 50 managers that lead small and average businesses in Gjakova municipality.

Through the interviev primary data have been collected and the reality of atitudes for effects of education in business and management based on views of owners and managers of businesess in gjakova municipality. While teoritical part of this work is discussed based on secondary data of professional texts 
and terciary data from the internet .At the end of this work through recomandations we gave some suggestions wich can lead to a solution ore relief of access agains this phenomenon.

\section{Definiton of business and management}

There are a lot of definitions for business and management, although sometimes business is defined as a trade activity in general as trade, sale, purchase, production, etc. So business we call any kind of economic activity usually privat that has as primary intent profit, in other way with the word business we understand even an enterprise or other economic organization.

Basedon the refence of Swedish national encyklopedy, (Nacinalencyklopedi, 1992, volume 7, pg.200.) fore the enterprise we have this definition: "Enterprise is the organization wich harmonizes work force, real capital, teqnique, information and knowledge to produce products and services".

Business in a basic unit is the one that organizes and kordinates factors of production, labor, land, capital and enterprising skills into the production process, it combines all these sources to produce diferent goods and services. There are also different metods to classify business according to their scaling, which are: small business, medium and large.

One another definition for business is that a "business is a group of people which work together for developing, producing or retailing goods or services". ${ }^{39}$

Management has also a lot of definitios but we are going to mention this one from professor I. Zeqiri, "management is an universal process of creating and achieving organizational purposes with and by other people, by using managerial funcitions like planning, organizing, leading and controlling, also by coordinating their resurse into an efficient and effective manner. ${ }^{40}$.

Management presents orientation of human activities towards specific goals by including 4 functions: planning, organizing, leading, and controlling. ${ }^{41}$. Hence management presents process through which a small group of a choosen people orientates and leads all the employis for achiving a common oranizational goal. ${ }^{42}$

\subsection{Educational impact into the menagers and human resources}

All the businesses including the small ones and large ones they have something in common, and that thing is need to be managed. The management is not onle a born talent but it also can be masterd. ${ }^{43}$ Regardless of the managerial and employee knowledge there is never enough knowledge to challenge the uncertainity that come from outside and even insade the organization. The managers and employees should always advance with their knowledge by the purpose that one day they will use it when its necessary.

Education, training and developement of the managers and employees are constant stroke for business for improving actual and coming performance. ${ }^{44}$

There are two whays for education: ${ }^{45}$

1. Formal education that includes real work, deepening the knowledge for the use of technology, career development for a more complicated managerial jobs etc.

2. Informal educaton that includes seminars, trainings, workshops, special topics. Education and devilopement has some potential effects: ${ }^{46}$

39 S. Robbins, D. DeCenzo, "Bazat e Menaxhimit", Tiranë, UET/Press, 2011, Fq.42

40 I Zeqiri, "Menaxhmenti", Tetovë, Tringa Design, 2006, fq.6

${ }^{41}$ B. Ramosaj, Ndërmarrja dhe menaxhmenti ndërmarrës, Rilindja, Prishtinë, 1991, fq. 24 .

42 J.L. Massic and Douglas, J, Managing: Acontemporary Introduction, Engewood

Cliffs, N. J., Perntace Hall, 1973, fq.24

${ }^{43}$ Sh. Llaci, Menaxhimi, ALB PAPER, Tiranë 2002, fq. 15

${ }^{44}$ E. Kutllovci, Menaxhimi I resurseve humane, UP, Prishtin, 2004, fq. 122

45 Y. Havolli, Menaxhmenti I resurseve njerezore, Riinvest, Prishtinë, 2005. Fq.106

46 E. Kutllovci, Menaxhimi I resurseve humane, UP, Prishtin, 2004, fq.126-127. 
a) Organizational effects: higher employiment, higher work quality, less expenses, higher walue, higher innovation, more flexibility etc.

b) Indual effects: higher job capability, contionus embloyment, higher flexibility and adaption

c) Team effects: group work, cooperation, autonomy, self-controll and flexibility.

d) Overall effects: higher organizational and individual profit, higher competitive abilitys, development and specialize.

Usually education is based on gaining new knowledges and cleverness for organizational members, for being capable to take new responsibilities and new challenges. ${ }^{47}$

\section{Research results - data analyse}

For trying to present as much as realistic situation about the education impact into the business also fort trying to achive right conclusions and recomandations we have kreated a questionare which is focused into education and his impact into the Gjakova. Data collected in the field is qualitative where are been surveyd about 30 business owners and 50 managers. Owners and managers have been choosen by chance. Another used method for calculating data is analitical method and comperative method.

Here are following results of the qustionare thaken from the business owners and managers

1. Does dhe educaiton has impact into the quality of outcomes, aslo into the improvement of goods and services?

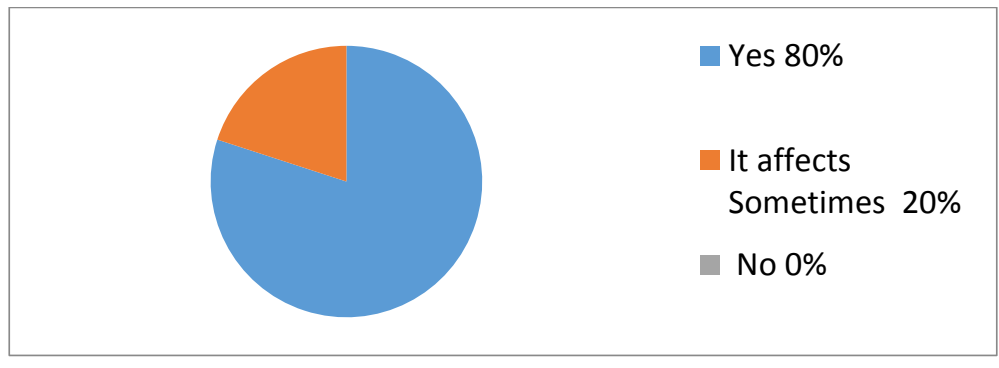

Resusts from a chart one show that $80 \%$ of interwiewers said that educatin has impact on the quality, also $20 \%$ agreed that sometimes affect and no one told that it does not have an impat into the business performance.

2. Does the education has impact into the business adaption, competitive capabilities and adoption for the changes?

\begin{tabular}{|l|l|}
\hline $12 \% \quad 0 \%$ & \\
& \\
$88 \%$ & -yes \\
& \\
& \\
& \\
& Sometimes \\
\hline
\end{tabular}

47 I Zeqiri, "Menaxhmenti", Tetovë, Tringa Design, 2006, fq.283 
Results from a second chart show that $88 \%$ of surveyed managers know that the education has an impact into businss capabilities to change and adoption. $22 \%$ think that education has sometimes impact but it is not necessary to be so.

3. Could we achive a higher employment, higher quality, higher value and even more innovation and less expenses thruough contious education?

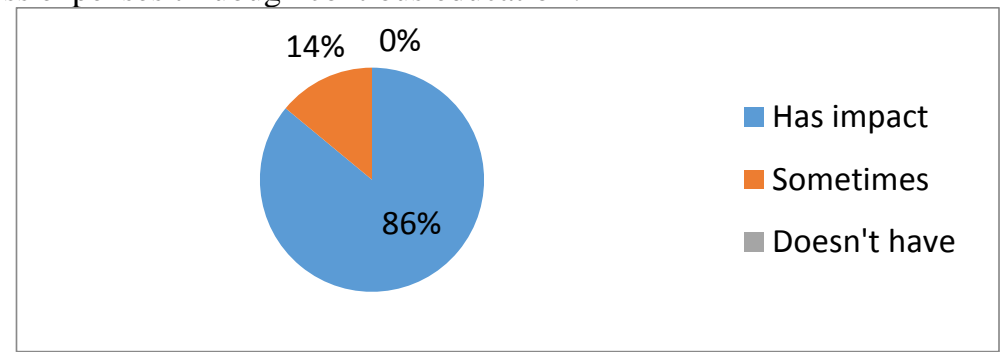

Results from the third chart show that $86 \%$ of menagers told that they are aware about the fact that the education has a lot of impact into these factors, another $14 \%$ of them didn't show full admittance but they were aware abot the fact and told sometimes it can affect these things.

4. Does the education make a better team work, cooperation, autonomy, self-controll and flecibility?

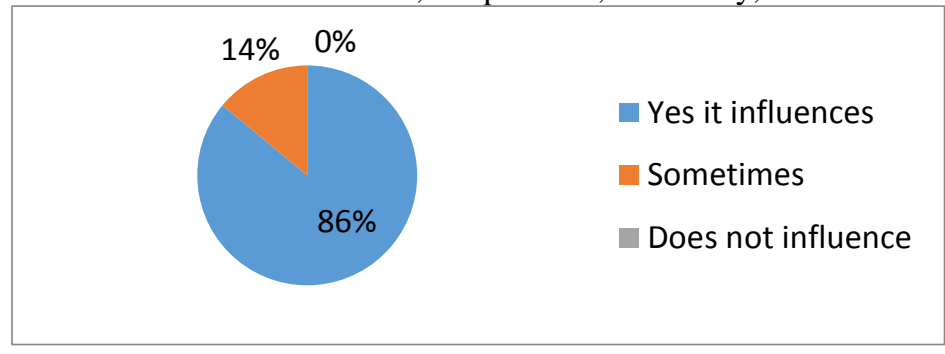

Resulst from this chart show that almost all managers are aware that education influences cooperation, team work and employee autonomy, $14 \%$ of them are aware that it influences but not all the time.

5. Do you make any effort to make your business more supportive for your emploees in moral or financial manner for formal or informal education of your employees?

\begin{tabular}{|ll|}
\hline $4 \% \quad 8 \%$ & Always \\
& \\
& Rarely we support \\
& them \\
& Never \\
& \\
&
\end{tabular}

$88 \%$ of menagers told that they rarely are supportive, $8 \%$ told that always support their employees and another $4 \%$ thold that never support their employees for their education.

Here are results taken by interwiewing the business ownes, and here are some of their answers about the educational impact into their business. 
6. Does the education help managers into analyzing and finding solutions for organizational probplems?

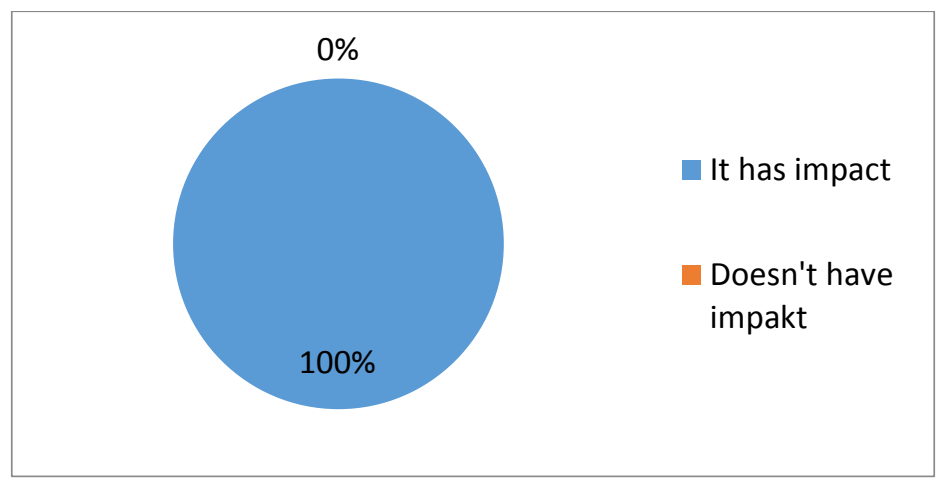

Results show that all the owners admit that the education has a good deed into the abilities of their managers.

7. Does the education help managers implement into the right manner all managerial funcitons?

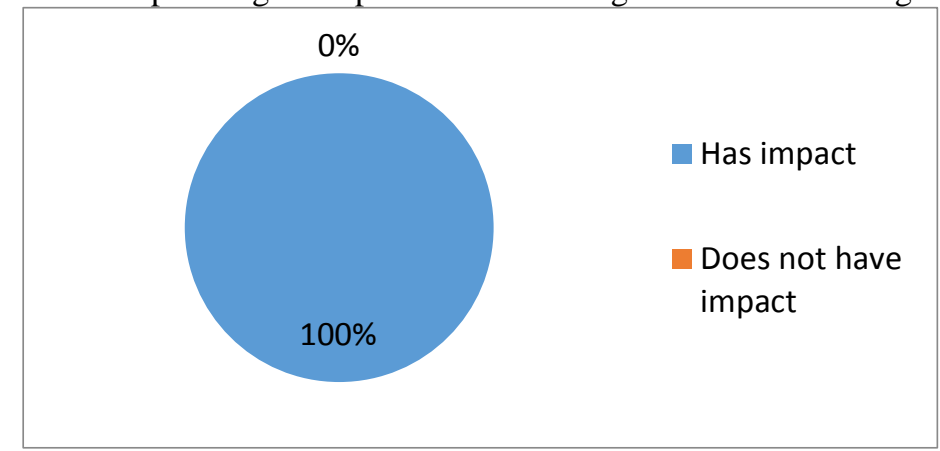

Also in this questin all the owner from some businesses of Gjakova are aware that and are convinced that the education of their managers, allows them to do job in the right manner and implement managerial functions in right way.

8. Does the education help managers being efficient and effective into their duty.

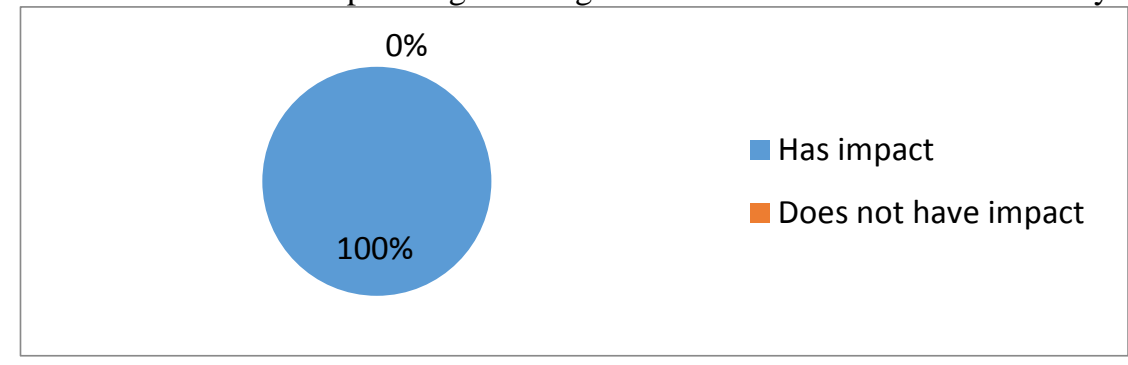

Result show that olso in this question all the business owners admit that their managers who have higher education are more effective and efficient when doing duties into an organization. 


\section{Conclusions and Recommendations}

Managers from Gjakova claim that education is fundamental for improvement of production, services, and productivity, as a result there are better organizational benefits also higher personal benefits, and as a result of all these it also has impact into public economy.

Most of the managers admit that education has impact into the competition growing, by preparation of human recoures, and this also helps into the developing of the business and achieving higher profits also better fiting for the changes.

Plenty of the mengaers which have been interwieved think that education has impact on the rate of employment. Also managerst think that educatin has impact into improving of the work abilities when work force is capable to find work any time they need, and this may be satisfaction for them. Alos they think that education enhances cooperation and makes a team work more pleasurable.

Also we can conclude that level of the educational support for the employees is not satisfactionary even that managers know the education importance and the imapt that education has into theri business.

As closure we can say that owners and managers into the Gjakova know the importance of educantin and that the effect of education that have into every business field, however in practice they do not support enough educational development for their employees, which soon or later will affect their working and business capabilities.

It is recommendet to the Gjakova managers to orien their strength and their efforts through the educationa of their own emplees and be more supportive because by doing that way they could be more stable and more competitive in one unestable environment like Kosovos.

The managers who whant to make higher work quality, raise overall business value, be more innovative, its recommendet to hire more skilled workers also they should support their further education.

Also the municipality of Gjakova should offer more trainings for lokal businesses including here owners, managers and employees, because in the end it all goes for collective goodness.

\section{References}

1. Havolli, Y., Menaxhmenti I resurseve njerezore, Riinvest, Prishtinë, 2005

2. Ingram, Th. Albright, and B. Baldwin, "Kontabilitetyi Financiar", Mason, Ohio USA, Thomson South-Western, 2003.

3. Konini, M., I Peçi, Fjalor ekonomik, Copyrighet CIVET, Tiranë, 1997

4. Koleci, B., F. Reçica, N. Turkeshi, Menaxhmenti, AAB, Prishtinë, 2008

5. Kutllovci, E., Menaxhimi I resurseve humane, UP, Prishtin, 2004

6. Llaci, SH., Menaxhimi, ALB PAPER, Tiranë 2002

7. Mançellari, A., S. Hadëri, Dh. Kule, S. Qirici, Hyrje në ekonomi, "PEGI",Tiranë, 2002

8. Massic,J.L. and Douglas, J, Managing: Acontemporary Introduction, Engewood Cliffs, N. J., Perntace Hall, 1973

9. Mustafa, I., Udhëheqja “Leadership”,Riinvest,Prishtinë,2004

10. Ramosaj. B, Ndërmarrja dhe menaxhmenti ndërmarrës, Rilindja, Prishtinë, 1991

11. Ramosaj, B., Management, UP, Prishtinë,2007

12. Robbins S., D. DeCenzo, "Bazat e Menaxhimit", Tiranë, UET/Press, 2011

13. Skenderi, N., "Fjalor Ekonomiko-Social”, Prishtinë, Blendi, 2010

14. Weihrich H, \& Horold Koontz, Management, Copyright McGraw, Inc. New York. 1993

15. Zeqiri, I.,"Menaxhmenti”, Tetovë, Tringa Design, 2006, fq.6 